\title{
Ethical challenges of public tourism policies in the face of the exacerbated crisis by the SARS-CoV-2 pandemic
}

\author{
Marutschka Martini Moesch, João Paulo Faria Tasso*
}

Keywords:
Public Policies in Tourism,
Ethics,
Covid 19,
Tourism Resumption.

Article History:

Submitted: 07.05.2021

Accepted: 10.12.2021

\begin{abstract}
The theme of this article focuses on the various (and contradictory) measures to deal with the disastrous consequences of the Covid-19 pandemic, that is, on the one hand, by encouraging the immediate resumption of Tourism leveraged by the current administration of the Federal Government of Brazil (such as a strategy to fight the economic crisis) and by protest actions by representatives of the productive sector of Tourism and, on the other hand, by popular demonstrations by residents of Brazilian tourist destinations, against such a resumption of the activity. So, the central question seems to be: how should national public policies be structured in order to mitigate the appalling negative impacts of the pandemic on the Brazilian economy (especially regarding unemployment and lack of income), without disregarding the fundamental commitment to health security of populations in tourist destinations, in view of the increase in the situation of disseminated contamination? The objective of the research is to analyze the contradictions that have been established between national public policies for the resumption of Tourism (in the fight against the economic crisis resulting from the Covid-19 pandemic) and the growing insecurity of populations in Brazilian tourist destinations in view of the expansion of the situation. of contamination. The theoretical foundation is based on: theories of the sociology of absences and emergencies, by Boaventura dos Santos; Hannah Arendt (2010) about the rise of the social sphere that undermined the original distinction between public and private, with action (praxis) being one of the fundamental human conditions. The theoretical-methodological path taken in the development of the essay is the multiple case study through the analysis of experiences, and the triangulation of speeches through analytical categories. The discussions that open from there permeate conceptual debates on an ethical foundation of public policies, to mitigate the effects of structural crises, and the current impact of the pandemic that devastates the world scenario. And if these are in the field of mitigation or irresponsible promotion, under the commitment to save jobs, opposing ethical attitudes in the exercise of imposing violence of legal authority, and the principles of public discussion on "mutual commitment and common deliberation".
\end{abstract}

Doi: https://doi.org/10.31822/jomat.2021-SP-1-7

"Fear blinds (...) these are the right words, we were already blind when we were blind, fear has blinded us, fear will make us remain blind"

(José Saramago, Essays on Blindness)

\section{Introduction}

What are we doing? This is the central theme of this article, which focuses on the analysis of the various (and contradictory) measures to deal with the disastrous consequences of the Covid-19 pandemic. On the one hand, initiatives based on encouraging the immediate resumption of Tourism have been recognized, leveraged by the current administration of the Federal Government of
Brazil (as a strategy to combat the worsening of the economic crisis) and by protest actions by representatives of the productive sector of the Tourism. On the other hand, popular demonstrations by residents of Brazilian tourist destinations, contrary to the adopted "necropolitics".

The discussions that initiate from there permeate some conceptual debates on an ethical foundation for public policies to mitigate the effects of structural crises, and the current impact of the pandemic that devastates the world scenario. 
The uncontrolled advance of the SARS-CoV-2 pandemic around the world has been showing alarming rates in the economic and social contexts. In Latin America, the entirely disjointed responses of governments, throughout the years 2020 and 2021, have resulted in the loss of an extremely high number of lives, highlighting the need for a common body. In the region, where $8.5 \%$ of the world's population live and where about a third of the deaths of the pandemic were registered (Brazil and Mexico are global epicenters), the result was extremely devastating: more than one million deaths, $44 \%$ in the Brazil and $22 \%$ in Mexico. On the other hand, until the beginning of March, the region represented only $03 \%$ of the total doses of vaccines against Covid-19 applied in the world, according to Carissa Etienne, Director of the Pan American Health Organization (PAHO) (Carta Maior, 2021).

More specifically in the case of Brazil, the recent report presented by the Central Bank, in February 2021, emphasized that, according to the Central Bank Activity Index (IBC-Br), the Brazilian economic activity closed the year 2020 with a retraction of $4.05 \%$ compared to 2019 (Terra, 2021). The registered unemployment rates were the historical highs: $14.7 \%$ in the 1 st quarter of $2021 ; 14.8$ million unemployed, of which 2.4 million were added in just one year (IBGE, 2021).

In this context, the World Bank reiterated the need to extend social assistance programs to the most vulnerable, as $50 \%$ of workers live in informality in Latin America (OCDE, 2020). There is talk of "socializing the damage" among governments, banks and companies caused by the SARS-CoV-2 pandemic.

With the global dissemination of coronavirus, tourism was certainly one of the most affected sectors. In a March 2021 article, The Economist (2021) predicted that business hotels will decline by at least $50 \%$ of congresses and work meetings that will likely never go back to the way they were if they can be held remotely (online). Business Tourism will practically disappear. Entertainment Tourism is expected to return in the second half of 2021, especially in countries that already have vaccination of at least $70 \%$ of the population, always accompanied by a lot of operating technology (from purchase, operation, until to experience itself). More than ever, people will appreciate and demand a visit to nature, but with technological solutions. More remote locations, authentic experiences, supported with 24/7 digital assistance.
In Brazil, government measures (federal, state and municipal) - many of them late - had to be taken to try to contain the increase in the number of cases and deaths, such as restrictions on movement (lockdown) and closing of public and private visitation spaces.

The asymmetries in the field of work in Tourism become more visible in the face of the pandemic. Hotels with very low occupancy, closed restaurants and bars, canceled events, as well as tourist attractions and parks, leave new unemployed in their wake. According to the National Civil Aviation Agency (ANAC), since April 2020, the number of flight operations has been reduced by 91.6\%. The number of cities served by Brazilian airlines decreased from 106 to 46, while the number of weekly flights declined from 14,781 to 1,241 (Flapper, 2021). After all, Tourism is a human phenomenon of large regional and global flows, which requires encounters, approaches, reception between different ones, and data from the air transport sector show a great impact on these flows.

Still, even with alarming rates - more than 17.4 million infected (until June 12, 2021), according to the Special Epidemiological Bulletin of the Health Surveillance Secretariat, of the Ministry of Health, and 486 thousand deaths (Datasus, 2021), maintaining an average of 2 thousand cases per day - even with this epidemiological picture, it has not been difficult to recognize leisure and visitation practices, in the midst of agglomerated groups of people, being developed normally in different parts of Brazil. Long holidays, festive dates and school and professional vacations have shown countless examples of disrespect for sanitary measures, such as crowded beaches (Ipanema-RJ, Capão da CanoaRS, Garopaba-SC, Pipa-RN), parties and nightclub openings (Barra de São Miguel-AL, Itacaré-BA, Anchieta-ES, Balneário Camboriú-SC), among others (G1, 2020a).

If it is unquestionable that it is not known how all this will develop and, specially, how long it will take to finish, it is understood that public policies need to be able to anticipate, in everything possible, in order to contain the social crisis that, no one doubts, will continue on the world scenario. State intervention is inevitable and providential at this critical moment. Even the most liberal economies have already converted and are clamoring for intervention, above all to save companies. But this intervention has to serve a clear strategy: to support employment and 
guarantee the base of support to those who need it most in this disastrous period of the pandemic.

Crisis only ceases to be destructive if it turns into a new opportunity for those most affected by it. And, for this, it is necessary that the themes and priorities aimed at mitigating the crisis are redefined, in order to enable forms of reinvention for workers and tourism businessmen.

It is important to remember that the current pandemic is not a crisis situation that is clearly opposed to the normal situation. Why? Since 1980, the world has been in a state of permanent crisis. Crisis, by its nature, is exceptional and temporary, and it provides an opportunity to overcome oneself and lead to a better situation.

The viral outbreak pulverizes this common being and evaporates security overnight. The pandemic is not blind and has privileged objectives, but it still creates an awareness of planetary communion, in a somewhat democratic way. The literal meaning of the SARS-CoV-2 coronavirus pandemic is the widespread chaotic fear, and borderless death caused by the invisible enemy, weakening the human condition of defending life, as not even the artificial world of things built by work is guaranteeing the fullness of life. Active life consists of things produced by human activities conditioning human existence.

So, the central question seems to be: how should national public policies be structured, in order to mitigate the amazing negative impacts of the pandemic on the Brazilian economy (especially regarding unemployment and lack of income), without disregarding the fundamental commitment to safety health of populations in tourist destinations, given the increase in the situation of disseminated contamination? What are we doing as a society?

In this sense, this article sought to:

a) demonstrate the role of public policies in the sphere of confronting the crises that have ravaged the world since the 1980s. Reason for bringing to the dialogue Hannah Arendt (2010) about the rise of the social sphere that undermined the original distinction between public and private, as one of the fundamental human conditions is action (praxis), which occurs only in the presence of other human beings, therefore in the public sphere, at a time controlled by the State. Sociological theories that indicate, as a point of discussion, how much public policy (in moments of social and economic crisis) incorporates the authority of a new political body, without resorting to an authoritarian absolute to solve social control in the expansion of the
Covid- 19 in tourist destinations, and point to the reductionist conception of what Tourism is, as one of the causes of the vulnerability suffered by tourist communities and the increase in the impacts of the health crisis on their futures.

b) address the necessary reincorporation of ethical bases to public tourism policies, aimed at mitigating the consequences of the Covid-19 pandemic. To explore the field of ethics, classical and contemporary authors were taken as reference, from a conception basis in Aristotle (1991) (for a study on moral values and human behavior, following a teleological order aimed at greater purposes beyond material accumulation ), through Spinoza (2009) (reaffirmed the nature of affection as an ethical necessity of the very nature of man), Weber (2006) (ethics and the spirit of capitalism), and modern thinkers such as Boff (2003) (coherence, prudence and ethical values), Bauman (2013) (postmodern ethics), among others.

c) present the theoretical methodological path taken in the development of the essay, such as the multiple case study and the triangulation of discourses. Qualitative research has an exploratory character on some object, deals with subjective aspects and reaches non-explicit or even unconscious motivations. These characteristics are also related to the object of study of the present work, constituting the most appropriate approach.

d) analyze the contradictions between data (official), manifestations (popular) and actions (governmental), evidenced in the period of deep socioeconomic crisis and sanitary insecurity, caused by the development of the pandemic. Describe the main actions of the Ministry of Tourism in the face of the Covid-19 pandemic crisis, recognizing whether they are in the field of mitigating the devastating effects or the irresponsible promotion of the resumption of Tourism (under the commitment to save jobs), opposing ethical attitudes in the exercise of imposing violence of legal authority, and the principles of public discussion on "mutual commitment and common deliberation", in light of the theoretical foundation of the sociology of absences and emergencies, by Boaventura dos Santos (2020).

\section{The role of public policies in dealing with crises}

The role of public policies in the sphere of confronting the crises that have plagued the world since the 1980s becomes more preponderant, given the global health crisis arising from the pandemic caused by the SARS-CoV-2 virus. The exceptionality experienced by society in the years 2019-2021 brings out extraordinary powers to executive authorities, to the detriment of legislative ones, and has an underlying idea of necessity. The so-called "emergency powers" by the legal field:

The powers of emergence are the tools used by public authorities to deal with temporary situations. They empower 
competencies and certain authorities to adopt exceptional measures and presuppose the idea that, in order to preserve public safety, swift and categorical decisions must be taken. Thus, rights and guarantees can be restricted, in order to guarantee the necessary efficiency to deal with the crisis situation, and then restore the previous conditions of operation of the constitutional system." (Barreto, 2020, sp.)

The reason for bringing to this dialogue Hannah Arendt (2010), about the rise of the social sphere that undermined the original distinction between public and private, with action (praxis) being one of the fundamental human conditions, which occurs only in the presence of other human beings, therefore, in the public sphere, now controlled by the State. Social sphere that indicates, as a point of discussion, how much public policy in moments of social and economic crisis embodies the authority of a new political body, without necessarily resorting to an authoritarian absolute. Solving the problem of social control in the expansion of the Covid-19 pandemic in tourist destinations has been a challenge for public authorities.

(...) politics is the science and the awareness of the actions of governments established by representations of public subjects. In this way, there is no way to link politics to the development of a people, of a polis, without placing oneself in politics, worked as a representation at the service of the formulation and establishment of common goods. (Alves, 2013, p.41)

With the pandemic, the debate about the limits of State action came to the fore. Different answers were taken around the globe, not always based on the parameters considered the most democratic.

Public policy presents a complex of means, mechanisms and social processes by which the subjects - civil society, public agents, government structures, behaviors and social movements that constitute society and contribute to modifying and developing it - are controlled consciously and integrated into the total ensemble, so that it is possible to outline, dominate and shape its future.

It gives priority to certain types of development, chooses focuses or poles of formation or increments of sectors/products, selects ways of propagation and forms of materialization of such socioeconomic advances, within the scope of society as a whole. It resolves tensions and conflicts that disturb, hinder or prevent the achievement of the chosen ends. It requires an authority capable of judging interests and demands that are not automatically compatible, or conflicting, of the subsets, subjects and agents whose decisions become norms for such interests and demands.

It supposes a strategy conceived as an organic body of decisions regarding a series of economic, social, cultural, political and ideological decisions, which results in an effective program that guides the intervention and planning public agencies to the recipients (national group, subgroups, social classes, groups, sectors, regions). The actions that are taken in the light of established public policy must translate into an organic set of objectives and means that are quantitatively and qualitatively evaluated and adapted to each other. They should interest the entire economy, society and the political system (preferably democratic), with determination of resources, instruments, stages, as well as attribution of tasks and responsibilities to the main social agents, in the executive, legislative and judicial spheres, such as in the municipal, state/regional and federal territorial dimension, the organic structure of the rule of law of modern democracies.

The republican meaning of public policy is made in an integrated and broadly representative way. It therefore opts for the re-encounter of the concept with the community, the real management in its effectiveness of management in the service of the public good, of what becomes common. But these republican guarantees are not always present in the State's actions. For, for modern society, being a free person means mastering oneself vital needs and thus "being free to transcend oneself own existence and enter the common world to all" (ARENDT, 1989, p.77).

\begin{abstract}
Common wealth, therefore, can never become common in the sense we atribute to the common world; it remained - or rather was intended to remain - strictly private. Common was only the government, appointed to protect private owners from each other in the competitive struggle for more wealth. The obvious contradiction of this modern concept of government, where the only thing people have in common are their private interests (...)" (ARENDT, 1989, p. 79)
\end{abstract}

The public space is the place for the practice of freedom, politics, citizenship, action, immortality, uniqueness and equality, the power of appearances (advertising) and the relationship between-the-subjects (PETRY, 2012). Practices that build the public sphere as territorialities of what is common, that is, the public. What for Arendt is what belongs to everyone, to the field of the common. Public policies, as a form of discourse, must take place in a public space, respecting the other as a possessor of speech, which allows a domain that equals individuals, recovering participation in the public sphere, so that government affairs enhance what is of public interest, which is common, replacing the essence of ethics in the use of authority. 
Understanding ethics (or "moral philosophy") necessarily implies assuming the understanding of a human process of adopting conducts and behaviors based on an analysis and reflection on different factors, and involving the dimensioning before, during and after - of the consequences of primary acts (Boff, 2003). It is a field of knowledge governed by a normative knowledge, whose intention is to offer guidance to human behavior through premises such as prudence, coherence, character and habits that do not result in harm to the congeners (Cortina, Orts, \& Navarro, 1996; Boff , 2003).

It is precisely these fundamental premises that, in effect, must be linked to the processes of creation and implementation of public tourism policies, conceived as active instruments of government intervention (Dye, 1992). The incorporation of ethical assumptions to public tourism policies must be permeated with decision-making processes, ensuring the democratization and legitimacy of the participation of different segments of society.

However, it should be asked: to what extent has ethics been contemplated in public tourism policies in Brazil, given the current context of the pandemic? Because the public, being a "nontangible" place - that is, it exists only when citizens gather, and breaks down when they disperse needs actors who merge and update public spaces. How to do it in time of pandemic?

Ethics, based on the Aristotelian reflection, comprises the part of philosophy that deals with moral values, practical human rationality, that is, actions that, in a teleological order, are always oriented to a specific purpose, a purpose that goes beyond the mere pursuit of material wealth. This "supreme end" (summum bonum) is what we mean by happiness (Aristóteles, 1991).

In the face of a severe health crisis, which is plaguing not only the Tourism sector but the entire social and economic conjucture in Brazil, it is essential that the government assume - in its various spheres of action - the commitment to seek to fulfill the real purposes linked tourism development in the territories. But, on ethical grounds, what would be the real purposes to be expressed in current public tourism policies, given the period of global crisis?

When we understand that Tourism is a field of historical-social practices, which presuppose the displacement of the subject(s), in times and spaces produced in an objective way, enabling symbolic departures from everyday life, covered in subjectivities (Moesch, 2000 ) - therefore, expliciters of an aesthetic in the face of the pursuit of pleasure - the flow of movement and of encounter, time-space relationship, is only possible due to the human desire to be-with, and, in this moment of pandemic, to be-with ( people and destinations).

Thus, the debate based on a time of pandemic crisis is opened in two controversial perspectives: the first, which takes as the main purpose of public tourism policies to combat the evident economic asphyxia faced by the sector, through the immediate resumption of tourist activities and the support structure to them, which is in the public sphere (which does not necessarily mean that it is state-owned); and the second, whose main purpose is to maintain the conditions of human existence life itself, birth, mortality, worldliness, plurality and planet Earth, according to ARENDT (1989, p.19), which ratifies the need to interrupt any and all non-essential activities (such as leisure practices by Tourism), as a way to prevent the collapse of the health system and the reduction of the growing contagion and death curves in the national territory.

\section{Methodological Path Taken}

The purpose of this study is to go beyond the appearance of the theme, It is to base existing concepts and create new ones, therefore, being a research with theoretical objectives. In this sense, the improvement of theoretical foundations is aimed at understanding what is included in the designation of the ethical challenges of public policies for tourism in the face of socioeconomic crises, taking into account their controversies and agreements, their explicit and implicit contents, contributing, thus, in the reconstruction of new perspectives that provide ethical mitigation policies and, consequently, a better coexistence between host communities and tourists.

In view of the objectives of the essay, qualitative analysis is the one that best suits its development, since its central focus, according to Minayo (1997), is in the social sciences, with a level of reality that cannot be quantified, that is, it works with the universe of meanings, motives, aspirations, beliefs, values, attitudes and social representations, which correspond to a deeper space of relationships, processes and phenomena that cannot be reduced to the operationalization of variables. The qualitative approach delves into human actions and relationships, a perceptible and non-capable 
side in equations, averages and statistics, as in the nature of quantitative research.

In qualitative research, according to Goldenberg (1999), the researcher's concern is not with the numerical representation of the researched group, but with the deepening of the understanding of a social group, an organization, an institution, of a trajectory.

Qualitative research has an exploratory character on some object. It deals with subjective aspects and reaches non-explicit or even unconscious motivations. These characteristics are also related to the object of study of the present work, constituting the most appropriate approach.

To cover the maximum amplitude in the description, explanation and understanding of the focus under study, the triangulation technique was used, which starts from principles that sustain that it is impossible to conceive the isolated existence of a social phenomenon, without historical roots, without cultural and without close and essential links with a social macro-reality (Triviños, 1987, p.138).

According to the triangulation technique, and supposing that we are studying specific subjects, the interest must be directed to processes and products centered on the subject. Then, the elements produced by the environment in which the subject is inserted, and which are responsible for their performance in the community. And, finally, the processes and products originated by the socioeconomic and cultural structure of the social macroorganism in which the subject is inserted.

In this research, the processes and products centered on the subject may correspond to a clipping of the manifestations expressed by the media, social networks, about the reactions to the health mitigation and control policies imposed, in 2020 and 2021, on Brazilian tourist destinations. The elements produced by the environment in which the subject is inserted may be represented by the actions of governments (at the federal, state and municipal levels) aimed at restricting and flexibilizing the norms for controlling the Covid-19 pandemic. And the processes and products originating from the socioeconomic and cultural structure in which the subjects are inserted can be analyzed by the global political and economic context, in view of the policies of the States in controlling the pandemic.
The investigation process went through:

- a provisional inventory of the own ideas, indicating the direction of the analysis and including the origins of interest in the subject;

- the historical and critical recovery of the production of sociological theories, seeking to identify perspectives for initial analysis and, later, the recovery of the proposed categories of analysis, such as ethics in public policies, mutual commitment and common deliberation regarding the source of authority of the new power system, and the reproduction and prolongation of the crises as a way to increase the invisibility of the impacted communities and nullify their confrontation experiences as forms of emancipation;

- the clipping of the broader totality explained from existing conditions and practices for analysis represented by news on social networks and media, of the involved actors.

A great deal of research is based on the in-depth study of particular cases, that is, on an intensive analysis undertaken within a single or a few real organizations. The case study gathers information as numerous and as detailed as possible with a view to learning the totality of a situation. (BRUYNE, 1982, p. 224).

For Bruyne (1982), case studies based on a theory, and referring to an object of knowledge that derives directly from it, tend to test the empirical validity of a system of methodologically constructed hypotheses with a view to experimental proof. The research mode becomes an empirical control field to test the value of theoretical propositions. The contraction of the present thus hides most of the inexhaustible wealth of social experiences in the world.

Criticism of metonymic reason ${ }^{2}$ is, therefore, a necessary condition for recovering wasted experience. What is at stake is the enlargement of the world through the enlargement of the present. Only through a new space-time will it be possible to identify and value the inexhaustible wealth of the world and the present. Simply, this new space-time presupposes another reason. (SantoS, 2011, p.88)

The metonymic reason for Santos (2002), despite of being much discredited, it's still dominant. The expansion of the world and the dilatation of the present must begin with a procedure he called the sociology of absences. It is an investigation that aims to demonstrate that what does not exist is, in fact, actively produced as non-existent, that is, as a non-credible alternative to what exists. Transforming impossible objects of knowledge into 
possible ones, and, based on them, transforming absences into presences, relying on the fragments of social experience, is what enables the theoretical-methodological interpretation of the sociology of absences.

To unveil the ideologies that guide social experiences, Santos (2002) coments in a sociology of absences the need to identify the scope of subtraction and contraction so that the experiences produced as absent are freed from these relations of production and, by this via, become present. Becoming present means being considered alternatives to hegemonic experiences of a colonialist and patriarchal character. The experiences of life lived in peripheral locations, and in coastal and rural tourist destinations whose credibility of their communities can be discussed and argued and their relationships with hegemonic experiences being the object of political dispute in the COVID-19 pandemic scenario, where the denial of science discourse is present.

By analyzing the experiences of community movements and sanitary containment actions by the local government, in the years 2020 and 2021, in Brazil, during the space-time of the pandemic, the following manifestations against the immediate resumption of Tourism were identified with the media (even without vaccination for the population under 60 years old):

Feelings of security (medical care, insurance policies, services of security companies, therapies, gyms, medications for longevity of life) combined with arrogance, and even condemnation towards all those who feel victimised by the same social solutions, have fallen by the wayside. The generalised chaotic fear and death without frontiers is invisibly present in pandemic timespace.

The manifestations against the resumption of tourism express a rupture with the secular conception of linear time, where the market directs the common sense of society.

The logic based on the monoculture of linear time (SANTOS, 2020), builds the idea that history has a unique and known meaning and direction that were formulated by the modern paradigm of rationality as: progress, revolution, modernization, development, growth, globalization.

The viral outbreak pulverizes this common sense and, by evaporating security from one day to the next, exposes the unpredictable to the immaculate absolute of the global market:
Common to all these formulations is the idea that time is linear and that the central countries of the world system follow in front of time and, with them, the knowledge, institutions and forms of sociability that dominate them. This logic produces non-existence by declaring backward everything that, according to the temporal norm, is asymmetric in relation to what is declared advanced. It is in terms of this logic that Western modernity produces the noncontemporaneity of the contemporary, the idea that simultaneity hides the asymmetries of the historical times that converge in it. (Santos, 2002, p.14)

The first systemic lesson is that "the whole is more than the sum of its parts". This means that there are emergent qualities, that is, that are born from the organization of a whole and that can be retroactive to the parts. In this case, the selfdetermination of tourist communities, on the logic of the territories' consumption market as mere goods devoid of lives. In the face of crises, history does not present itself as a straight line or a cumulative process as the progressive version preaches.

Manifestations against tourist practices during the COVID-19 pandemic by communities such as São Sebastião, on the coast of the State of São Paulo, where 250 local people created a barricade of burnt tires on the Oswaldo Cruz Highway, in order to prevent access by visitors, demonstrates the insertion of the social into the economy. At opposite poles, the community that produces common wealth becomes an agent of its paralysis, resisting the demands stimulated by travel agencies and MTur to practice tourism in a safe way. The construction of a feeling of security in the face of the invisible threat of the virus, as if it were possible, like the linear time-spaces that, according to security standards, arrogantly permeated the control over any risks.

The visible as an experience, represented here by the tourist demand of the metropolis - São Paulo -, versus the courage of the tourist community, as a political virtue of the "invisible", as they are only part of the "productive chain of tourist activity", explain the debate between the gloomy interior of the production chain, as part of the division of labor, to the light of the public sphere, as the use of those who are common, for all, the territory with its exuberant nature.

The exposure of human frailty by the pandemic caused dramatic positions in defense of life in tourist communities. As, for Bauman:

Sense of community is all that we miss and need to live safe and confident, what would be a lost paradise, but to which we eagerly await return, and so we feverishly search for the paths that can take us there. (Bauman, 2003, p.101) 


\section{]omatt}

The simulacrum of death, expressed in Table 1, presented by a resident on an access road to a tourist resort, at the beginning of a long holiday, represents the "vita activa" dedicated to public and political affairs, replacing the absences of policies for the preservation of life. For, what touches human life immediately assumes the character of a condition of human existence, according to Arendt (1989, p.17).

The conservative idea that there is an alternative to the way of life imposed by hypercapitalism falls

Table 1: Manifestations against the resumption of Tourism during the space-time of the pandemic

\begin{tabular}{|c|c|}
\hline $\begin{array}{l}\text { City Hall of São } \\
\text { Sebastião (SP) }\end{array}$ & $\begin{array}{l}\text { It set up a sanitary barrier on the border with the city o } \\
\text { Covid-19 tests to all occupants of vehicles with license }\end{array}$ \\
\hline $\begin{array}{l}\text { Local Community of } \\
\text { Ubatuba (SP) }\end{array}$ & $\begin{array}{l}250 \text { local people constructed a barricade of burned } \\
\text { tires on the Oswaldo Cruz Highway, in order to stop } \\
\text { access to visitors. }\end{array}$ \\
\hline $\begin{array}{l}\text { Local Community of } \\
\text { São Sebastião (SP) }\end{array}$ & $\begin{array}{l}\text { Ironic reactions: "welcome" by a person dressed as } \\
\text { Death on the Rio-Santos highway, and a surfer } \\
\text { dressed as Death on the beach at Maresias. }\end{array}$ \\
\hline $\begin{array}{l}\text { City Hall of Poços de } \\
\text { Caldas (MG) }\end{array}$ & $\begin{array}{l}\text { Sanitary barriers were installed at the entrances to the } \\
\text { municipality, prohibiting the entry of tourists. }\end{array}$ \\
\hline $\begin{array}{l}\text { Government of the State } \\
\text { of Rio de Janeiro (RJ) }\end{array}$ & $\begin{array}{l}\text { Publication of decree with restrictive measures for the } \\
\text { of the capital from traveling to the interior during a lon }\end{array}$ \\
\hline $\begin{array}{l}\text { Municipalities on the } \\
\text { coast of Paraná (PR) }\end{array}$ & $\begin{array}{l}\text { Sanitary barriers preventing the entry of tourists and } \\
\text { visitors into municipalities, seeking to contain the } \\
\text { spread of the pandemic in the region, and restricting } \\
\text { the arrival of residents from Curitiba. }\end{array}$ \\
\hline $\begin{array}{l}\text { Municipality of Magé } \\
\text { (Baixada Fluminense) }\end{array}$ & $\begin{array}{l}\text { Sanitary barriers, set up by the Municipal Secretariat } \\
\text { for Protection and Civil Defense of Magé, to prevent } \\
\text { more than } 30 \text { buses and tourist vans from accessing } \\
\text { the waterfalls in the area. }\end{array}$ \\
\hline
\end{tabular}

Sources: Yahoo! Noticias, 2021; Blog Ricardo Antunes, 2021; LeiaJa Nacional, 2020; G1, 2021a; Portal Giro, 2021; G1, 2021 (b); O Dia, 2021. 
apart, when in the name of "economic recovery" is suggested the threat to life.

On the other hand, demonstrations in favor of the immediate resumption of Tourism, led by representatives of the productive sector (business), added to the discontent of visitors and vacationers, all them against the measures to contain free movement on beaches and in visitation popular points, applied by local and state governments. Table 2 indicates the manifestations in favor of the immediate resumption of tourism during the spacetime of the pandemic, captured in social network between March 2020 and May 2021, related to public tourism policies analyzed in this article.

The social elasticity for the dominant way of life as a type of work, consumption, leisure, coexistence and, of postponing or anticipating death, are relatively rigid, and gradually change over the course of the dynamics of history and political struggles. The pandemic does not accept delays, it requires drastic changes.

The moment goes beyond the notion of regulation through self-production and self-organization. The construction of nature, as something external to society, obeys the constitution of a world economic system centered on the exploitation of natural resources, without understanding the systemic complexity in the society-culture-nature relationship. It is a generating curve in which products and effects are themselves producers and causers of what they produce. Thus, we individuals are products of a reproduction system that goes back to the depths of time, but this system can only reproduce if we ourselves become its producers by mating. Human individuals produce society in and through their interactions, but society as an emergent whole produces the humanity of these individuals by providing language and culture. So, like shadows that visibility creates.

Have we lost the preventive imagination and the political capacity to put society's defense into practice? Public policies in Tourism lack the political capacity to answer to these times of emergency.

Among the necessary characteristics for harmonizing the rule of law with the emergency situation is the publicity of its declaration and the mismatch between the authority that declares and the one that exercises emergency powers. Furthermore, it is important that the measures taken by governments respect some time limit, are subject to control by other instances of power, are necessary for legitimate purposes and are proportionate to the restrictions on the liberties suffered. (BARRETO, 2020, s.p)
Governments must provide clear and accurate information to residents and visitors about the massive growth of the new coronavirus, reinforcing the disastrous consequences brought about in the midst of the public and sanitary calamity that has been established in regions of wide tourist interest, and about the necessary restrictive measures adopted. Authorities must not endorse speculations that are not supported by real facts and science.

Other than that, public emergency and containment measures must be communicated widely, transparently and clearly, and nondiscriminatory. In this sense, it is expected that governments not only adopt non-neglected postures, but also take positive actions against discrimination, in order to reduce more accentuated risks among vulnerable groups. During the current pandemic, for example, it became evident that the virus disproportionately affects indigenous peoples, blacks, women, migrants and other minorities. Therefore, they must be included primarily in health strategies and social and economic policies to respond to the crisis.

However, the proposal of building public policies on ethical bases - that is, based on a greater purpose of common good, in which the idea of progress and development of a destination is not reduced to the economic component - seems to be far from the real initiatives of the Brazilian public power in federal and state spheres. What can be identified are, precisely, governmental actions to encourage the immediate resumption of the sector's activities, without any prudence or critical evaluation as to the irreversible sanitary and human consequences that such initiatives may have in the near future. Some of them can be highlighted as follows.

For Tasso, Moesch, Nóbrega (2021), the dissociation between "ethics" and "public policies" in Tourism can be noticed by the abdication of purposes aimed at the common good, and by the reproduction of the final logic of stimulating the growth of tourist flows - sometimes in a saturated way (overtourism) - and of expansion of consumption. The lack of centralized coordination to fight the COVID-19 pandemic, without responsible and sustainable planning that recognizes the limits of sanitary safety of tourist ecosystems, and that reaches the entire tourist community and benefits it equitably, is not present in the face of misguided communication at the federal, state and municipal levels. 


\section{Jlomat}

Table 2: Manifestations in favor of the immediate resumption of Tourism in the space-time of the pandemic Favorable to the immediate resumption of tourism

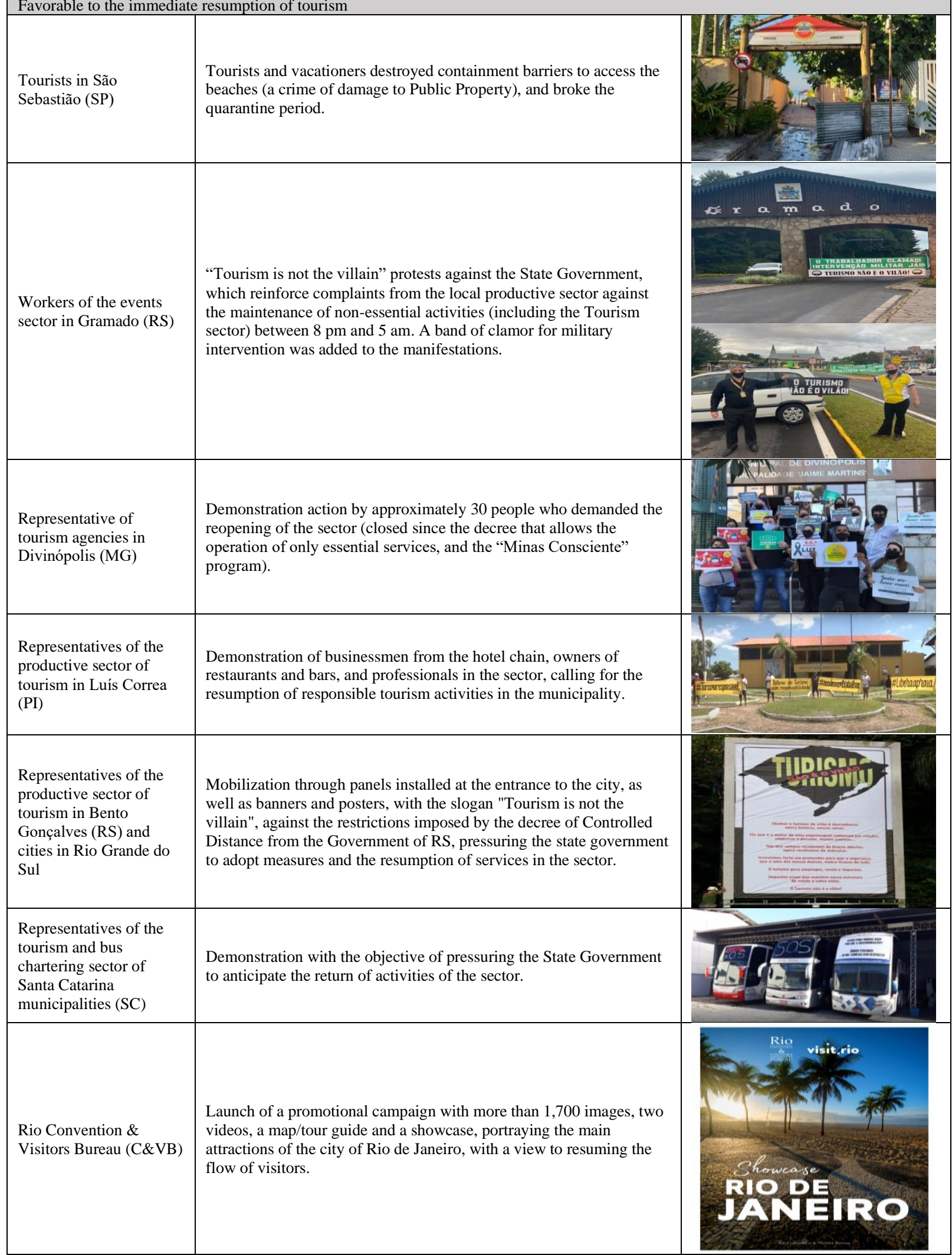

Sources: CNN Brasil, 2021; Portal MartinBehrend, 2021; Trendsmap, 2021; G1, 2020 (b); Programas MN, 2020; Seminário, 2021; alexandrejose.com, 2020, Panrotas, 2021. 
Table 3: Demonstrations of government incentives for the immediate resumption of tourism

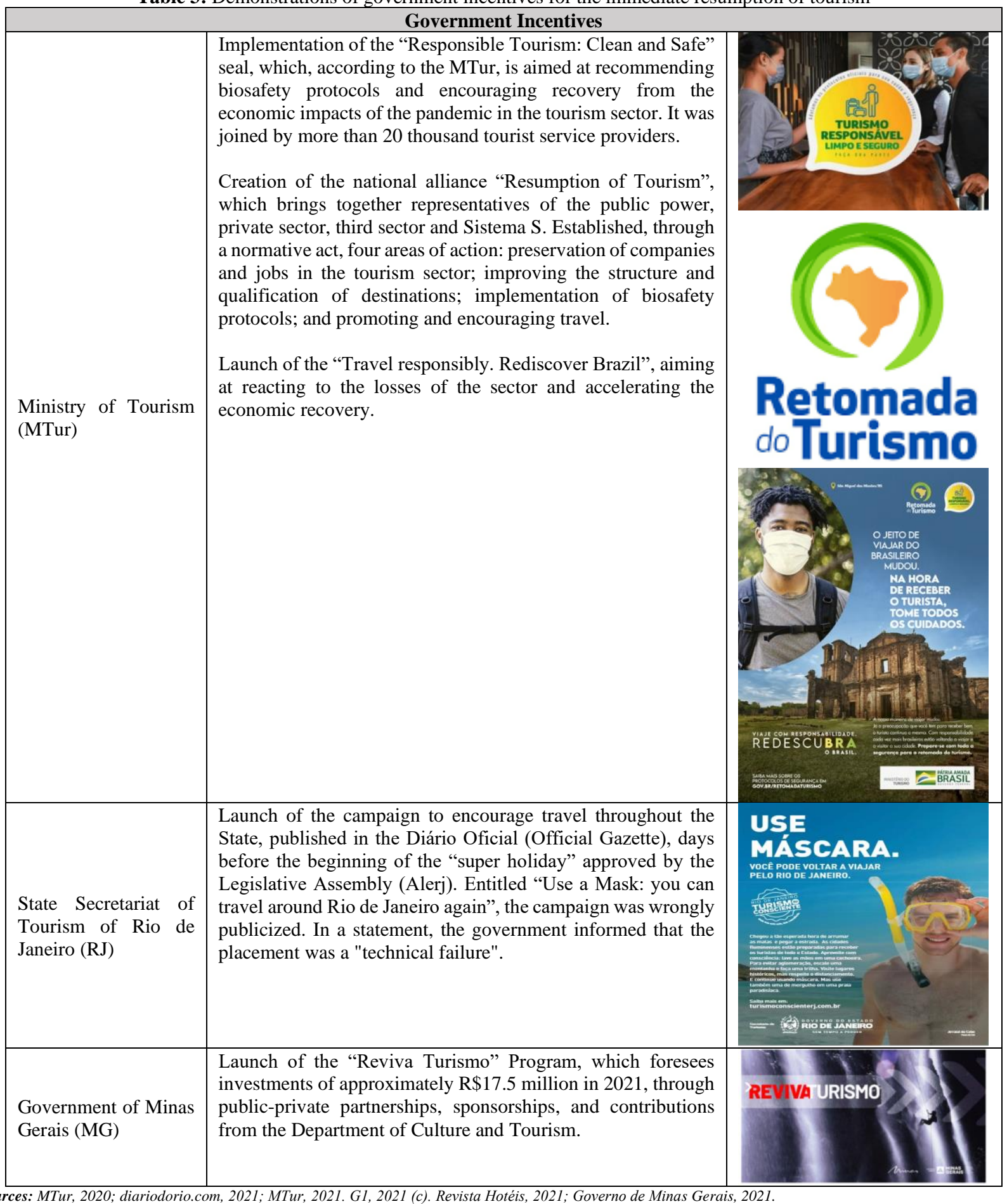

with ambitious, unrealistic, hard, structured "topdown" targets, exclusively focused on the quantitative approach and economic and financial aspects, aiming at generating income/revenues/currencies, employment and taxes, and with these measures, it encourages an irresponsible resumption of tourism in the territories. Actions such as the seal "Responsible Tourism: Clean and Safe", creation of the national alliance "Resumption of Tourism" and the campaign "Travel with responsibility. Rediscover Brazil", are much more similar to a market program that is concerned only with the final context of the productive sector, with the concern 
for the possible end of work in a labor society, than with human lives and the continuity of sustainable tourism. By the government departments responsible for Tourism, it is evident that they only listen to business interests (tourism trade) and individual ambitions, hurting the right to participation and the role of equity in public policies.

For Hannah Arendt, freedom is not the modern and private freedom of non-interference, but the public freedom of democratic participation, calls our attention to the fact that the freedom of necessity (production) is not to be confused with the freedom of the public space of word and action. (ARENDT, 1989).

Public debate exists for Arendt (1989) as a fundamental space for many and decisive issues that require a choice that cannot find its foundation in the field of certainties, "things that are not governed by the rigors of the field of cognition and that are not subordinate, therefore, to the despotism of the one-way path of one truth" (p. 29).

The process of building public policies consists of an incessant back and forth between certainties and uncertainties, between the elementary and the global, between the separable and the inseparable. It is not a question of abandoning the principles of classical science - order, separability and logic but of integrating them into a scheme that is both broader and richer. It is not a question of opposing a global and empty holism to a systematic reductionism; it is about linking the concrete - the experiences - of the parts to the totality. It is necessary to articulate the principles of order and disorder, separation and junction, autonomy and dependence, which are at the same time complementary, competing and antagonistic, within the universe of certainties of a pandemic time-space.

The absence of federal government public policies evidenced by the different uncoordinated actions such as the distribution of emergency aid to citizens and companies; strengthening the false dichotomy between social isolation versus jobs and income; corruption in vaccine procurement processes, causing huge delays in mass vaccination; added to the continuous propagation of fake news on social networks, by members of the pro-government executive and legislative branches, indicating the use of drugs not recommended by the WHO to the detriment of vaccination, as the no need to use masks creating false controversies arrives to the level of a necropolitics.

Faced with this chaos, the disoriented population makes individual decisions on what to do to face the health crisis. In this context of chaos, the impacts of unemployment are added to an index of 14.6\% (Agência Ibge Notícias, 2021), the highest level since 2012, and the inflation projected for 2021 by the Central Bank of $7.27 \%$ (G1, 2021d). The 2008 global financial crisis, which at that time had been mitigated by the public, including those of a social nature, widened the abyss between the poor and the rich, sharpening the social disruption, putting the country back on the hunger map.

In the speeches of the politicians to save economy, it is necessary to risk of sacrificing lives, those who cannot be confined to bring food, security services, cleaning, and care to the confined. Politically we do not exist in isolation, but we just coexist. According to Santos (2020), philosophically we can think in isolation, in a duality of coherent dialogue between the self and itself, but politics in its plurality requires always being connected to others, because if we can think for ourselves, we can only act collectively. Challenge imposed at this moment of exceptionality, whose best way to be solidary is to distance one to another.

\section{Final Considerations}

In this great social, economic, moral and disruptive crisis, it is necessary to imagine democratic solutions, based on the radicalization of participatory democracy at the neighborhood and community level, and on citizen education, aimed at solidarity and cooperation, with less entrepreneurship and competitiveness at all cost.

As the task to be shared by everyone has to be realized by each one under entirely different conditions, which divides human situations and induces harsher competition, instead of unifying a human condition inclined to generate cooperation and solidarity (Bauman, 2003, p. 122). It is not enough to share a territory, it is added to this economic and social sharing to weave the bonds of solidarity and belonging.

A world which is going through a moment of intense transformations needs to be thought about its most urgent issues: the multiple ways in which violence is exercised, the incessant increase in inequality, damage to the environment and the beings that inhabit the Earth, the violation of rights human rights, the militarization of territories and the impact of a pandemic on the 
social corpus, especially in its most vulnerable sectors. Context that replaces the role and urgency of democratic and ethical public policies.

What should be done? The virus calls us to action.

a) Diagnostics with groups weakened by the pandemic, pincipally in traditional communities, and in community-based tourism

b) By identifying fragile groups in the territories, create networks of solidarity cooperation.

c) To transfer income in a public policy of professional qualification, through scholarships, guaranteeing a minimum income for tourism workers

d) Do not work alone, strengthen networks of cooperation, solidarity economy, care for life. Build community resistance.

In this essay, far from documenting pessimism towards the possibilities of ethical public policies in public spaces, the aim is to use theoretical tools to transform the situation of injustice into an incessant exercise that unites theory with practice, thus lightning to social fragments of tourist practices in the pandemic space-time to reduce the possibilities of a "necrotourism" to settle there.

\section{References}

Agência Ibge Notícias. (2021). Desemprego fica em 14,6\% no trimestre até maio e atinge 14,8 milhões de pessoas. Retrieved on July 30, 2021.from https://agenciadenoticias.ibge.gov.br/agencianoticias/2012-agencia-de-noticias/noticias/31255desemprego-fica-em-14-6-no-trimestre-ate-maioe-atinge-14-8-milhoes-de-pessoas

alexandrejose.com. (2020). Setor de turismo fará manifestação nesta segunda-feira pedindo a retomada das atividades. Retrieved on June 07, 2020

https://alexandrejose.com/2020/06/setor-deturismo-fara-manifestacao-nesta-segunda-feirapedindo-a-retomada-das-atividades/

Alves, L. R. (2013). Políticas públicas integradas, ou, a Gestão que se encontra com a sociedade concreta e diversa. In VIEIRA, A. M., CASTRO, D. S. P., OLIVEIRA, R. J. (org). Políticas Públicas integradas: metodologias participativas e casos. São Bernardo do Campo/SP. Universidade Metodista de São Paulo.

Arendt, H. (1989). As Origens do Totalitarismo. São Paulo: Companhia das Letras.

Aristóteles. (1991). Ética a Nicômaco. Livro I. Nova Cultural.

Barreto, M. S. (2020). Exceção e emergência. Revista Nexo,23 Nov. 2020.
Bauman, Z. (2003) Comunidade: a busca por segurança no mundo atual. Rio de Janeiro: Jorge Zahar Ed.

Blog Ricardo Antunes. (2021). Moradores de Ubatuba (SP) queimam pneus para impedir a entrada de turistas. Retrieved on March 30, 2021 from https://ricardoantunes.com.br/moradores-deubatuba-sp-queimam-pneus-para-impedir-aentrada-de-turistas/

Bruyne, P. (org.). (1982). Dinâmica da Pesquisa em Ciências Sociais: os polos da prática metodológica. Rio de Janeiro: F. Alves.

Boff, L. (2003). Ética y moral: La búsqueda de los fundamentos. Bilbao: Editorial Sal Terrae.

Carta Maior. (2021). A América Latina vai mudar. Retrieved on March 28, 2021 from https://www.cartamaior.com.br/?/Editoria/PeloMundo/A-America-Latina-vai-mudar/6/50229

Cnn Brasil. (2021). Turistas derrubam barreiras e desrespeitam medidas nas praias de São Sebastião. Retrivied on March 28, 2021 from https://www.cnnbrasil.com.br/saude/2021/03/28/t uristas-derrubam-barreiras-fisicas-edesrespeitam-medidas-em-sao-sebastiao

Cortina, A., Orts, A., Navarro, E. M. (1996). Ética. Madrid: Ediciones Akal.

Datasus. (2021). COVID-19: Painel Coronavírus. Retrivied on June 03, 2021 from https://covid.saude.gov.br/

diariodorio.com. (2021). Governo do RJ comete gafe e incentiva turismo no estado durante o 'superferiado'. Retrieved on March 24, 2021 from https://diariodorio.com/governo-do-rj-cometegafe-e-incentiva-turismo-no-estado-durante-osuperferiado/

Dye, T. R. (1992). Understanding public policy. Englewood Cliffs, NJ: Prentice Hall.

Flapper. (2021). O impacto do coronavírus no setor de aviação no Brasil. Retrieved on April 04, 2021 from https://www.flyflapper.com/stories/pt-br/oimpacto-do-coronavirus-no-setor-de-aviacao-nobrasil//

G1. (2020a). Em meio à pandemia, Brasil tem festas e aglomerações com a proximidade do Ano Novo. Retrieved on December 31, 2020 from https://g1.globo.com/bemestar/coronavirus/noticia /2020/12/31/em-meio-a-pandemia-brasil-temfestas-e-aglomeracoes-com-a-proximidade-doano-novo.ghtml

G1. (2020b). Representantes de agências de turismo fazem manifestação pedindo retomada do setor em Divinópolis. Retrieved on August 13, 2020 from https://g1.globo.com/mg/centrooeste/noticia/2020/08/13/representantes-deagencias-de-turismo-fazem-manifestacaopedindo-retomada-do-setor-em-divinopolis.ghtml 
G1. (2021a). Barreiras que impedem a entrada de turistas começam a funcionar em Poços de Caldas, MG. Retrieved on March 24, 2021 from https://g1.globo.com/mg/sul-deminas/noticia/2021/03/24/barreiras-queimpedem-a-entrada-de-turistas-comecam-afuncionar-em-pocos-de-caldas-mg.ghtml

G1. (2021b). Municípios do litoral do paraná vão manter barreiras sanitárias até a Páscoa. Retrieved on March 26, 2021 from https://g1.globo.com/pr/parana/noticia/2021/03/26 /municipios-do-litoral-do-parana-vao-manterbarreiras-sanitarias-ate-a-pascoa.ghtml

G1. (2021c). Governo de Minas lança programa para retomada do turismo e prevê investimento de cerca $\mathrm{R} \$ 17 \mathrm{mi}$. Retrieved on June 11, 2021 from https://g1.globo.com/mg/minasgerais/noticia/2021/05/10/governo-de-minaslanca-programa-para-retomada-do-turismo-epreve-investimento-de-cerca-r-17-mi.ghtml

G1. (2021d). Analistas do mercado sobem a estimativa de inflação para $7,27 \% \%$ e veem alta menor do PIB. Retrieved on August 30, 2021 from https://g1.globo.com/economia/noticia/2021/08/30/ analistas-do-mercado-sobem-para-727percentestimativa-da-inflacao-em-2021-e-veem-altamenor-do-pib.ghtml

Governo De Minas Gerais. (2021). Reviva Turismo. Retrieved on August, 30, 2021 from file:///D:/Joao\%20Paulo/Downloads/Reviva\%20Tu rismo.pdf

Ibge. (2021). Desemprego fica estável em 14,2\% no trimestre encerrado em janeiro. Retrieved on March 31, 2021 from https://agenciadenoticias.ibge.gov.br/agencianoticias/2012-agencia-de-noticias/noticias/30390desemprego-fica-estavel-em-14-2-no-trimestreencerrado-em-janeiro

LeiaJa Nacional. (2020). 'Morte' surfa em Maresias alertando sobre aglomerações. Retrieved on September 17, $2020 \quad$ from https://www.leiaja.com/noticias/2020/09/17/morte -surfa-em-maresias-alertando-sobreaglomeracoes/

Mendiola, I. (2017). De la biopolítica a la necropolítica: la vida expuesta a la muerte. Eikasia: revista de filosofía, n. extra 75, p. 219-248.

Minayo, M. C. S. (org). (1987). Pesquisa Social - Teoria, método e criatividade. Petrópolis: Vozes.

MTur. (2020). Limpo e seguro: Selo Turismo Responsável chega a marca de 20 mil prestadores de serviços. Retrieved on September 01, 2020 from https://www.gov.br/casacivil/ptbr/assuntos/noticias/2020/setembro/limpo-eseguro-selo-turismo-responsavel-chega-a-marcade-20-mil-prestadores-de-servicos
MTur. (2021). Retomada do Turismo: conheça as medidas para a retomada do turismo. Retrieved on June 11.2021 from https://retomada.turismo.gov.br/

Ministério Da Saúde. (2020). Painel Coronavírus. Retrieved on September 25, 2020 from https://covid.saude.gov.br/

Moesch, M. M. (2000). A Produção do saber Turístico. São Paulo, SP: Ed. Contexto.

Molina, S. (2003). O Pós-Turismo. São Paulo, SP: Aleph.

Morin, E. (2006). Complexidade e Ética da Solidariedade. In: CASTRO,G.(org) Ensaios de Complexidade. $4^{\mathrm{a}}$ ed. Sulinas: Porto Alegre.

Organização Para A Cooperação E Desenvolvimento Econômico (Ocde). (2020). Combatendo o coronavírus (COVID-19) contribuindo para um esforço global. Retrieved on September 29, 2021 from https://www.oecd.org/coronavirus/pt/

O Dia. (2021). Barreiras sanitárias impedem entrada de veículos de turismo em Magé. Retrived on March 29, 2021 from https://odia.ig.com.br/rio-dejaneiro/2021/03/6115551-barreiras-sanitariasimpedem-entrada-de-veiculos-de-turismo-emmage.html

Panrotas. (2021). Rio CVB lança material de divulgação da cidade para retomada. Retrieved on June 11, 2021 from https://www.panrotas.com.br/mercado/destinos/2 021/05/rio-cvb-lanca-material-de-divulgacao-dacidade-para-retomada_181856.html

Portal Giro. (2021). Medidas que impedem ida de oradores da capital para o interior do Rio durante feriadão serão decretadas, diz Cláudio Castro. Retrieved on March 23, 2021 from http://portalgiro.com/medidas-que-impedem-idade-moradores-da-capital-para-o-interior-do-riodurante-feriadao-serao-decretadas-diz-claudiocastro/

Portal Martinbehrend. (2021). Protestos em Gramado e Canela pedem mais flexibilizações para o setor turístico. Retrieved on March 23, 2021 from https://www.martinbehrend.com.br/noticias/notic $\mathrm{ia} / \mathrm{id} / 9415 /$ titulo/protestos-em-gramado-e-canelapedem-mais-flexibilizacoes-para-o-setor-turistico

Programas MN. (2020). Manifestação pede retomada do turismo de Luís Correia. Retrieved on July 16, 2020 from https://www.youtube.com/watch?v=BivdNPNg-gk

Revista Hotéis. (2021). Viagem de lazer ganha espaço na retomada do turismo doméstico. Retrieved on June $12, \quad 2021$ from https://www.revistahoteis.com.br/viagem-delazer-ganha-espaco-na-retomada-do-turismodomestico/ 
Santos, B. (2002). Para uma sociologia das ausências e uma sociologia das emergências. Revista Crítica de Ciências Sociais, 63, CES, Universidade de Coimbra/PT, p. 237-280.

Seminário. (2021). Manifestação do setor de turismo pede o retorno das atividades em Bento Gonçalves. Retrieved on March 23, 2021 from https://jornalsemanario.com.br/manifestacao-dosetor-de-turismo-pede-o-retorno-das-atividadesem-bento-goncalves/

Tasso, J. P. F., Moesch, M. M., \& Nóbrega, W. R. M. (2021) Reincorporação da Ética às Políticas Públicas de Turismo: uma necessária reflexão no combate às consequências do Covid-19. Revista Brasileira de Pesquisa em Turismo, São Paulo, 15 (1), p. 2141, jan./abr. http://dx.doi.org/10.7784/rbtur.v15i1.2141

Terra. (2021). Economia brasileira fechou 2020 com retração de 4,05\%. Retrieved on February 12, 2021 from https://www.terra.com.br/economia/economiabrasileira-fechou-2020-com-retracao-de405,1bfc77939396bb59272792f44e64f131f9zfue42 .html\#: :text=BRAS\%C3\%8DLIA $\% 20 \% 2 \mathrm{D} \% 20 \mathrm{E}$ m\%20um\%20ano\%20marcado,permite\%20compa ra\%C3\%A7\%C3\%B5es\%20entre\%20os\%20anos

The Economist. (2021). O mundo em 2021. Retrieved on March. 2021 from https://bit.ly/3tYsHAE

Trendsmap. (2021). Gramado- RS. Twitter @CristianBasei. Retrieved on March 23, 2021 from https://www.trendsmap.com/twitter/tweet/13743 34635325468675

Triviños, A. N. S. (1987). Introdução à Pesquisa em Ciências Sociais. São Paulo: Atlas.

Yahoo! Notícias. (2021). Turistas no litoral de SP são "recepcionados" com fantasia de morte e pneus queimados. Retrieved on March 27, 2021 from https://br.noticias.yahoo.com/turistas-litoral-spsao-recepcionados-fantasia-morte-pneusqueimados181515613.html?guccounter=1\&guce_referrer=a HR0cHM6Ly93d3cuZ29vZ2xlLmNvbS8\&guce_re ferrer_sig=AQAAAGxH0VfSEeOGlG0W6uguo549ojP8aujTr54Idgri9S7LT9RObKx28p PLgMd5qV0g8t3f32H1uvSis7z7GTTgOUYMvDQ FklJ2FgEPr15P7K271uLYk89XiYSQmFbechzzNl2dInbqg1I2oxZRMRJDG0qIdQAP7Dq osCsCjGU2fx 


\section{INFO PAGE
Ethical challenges of public tourism policies in the face of the exacerbated crisis by the SARS-CoV-2 pandemic \\ Abstract}

The theme of this article focuses on the various (and contradictory) measures to deal with the disastrous consequences of the Covid-19 pandemic, that is, on the one hand, by encouraging the immediate resumption of Tourism leveraged by the current administration of the Federal Government of Brazil (such as a strategy to fight the economic crisis) and by protest actions by representatives of the productive sector of Tourism and, on the other hand, by popular demonstrations by residents of Brazilian tourist destinations, against such a resumption of the activity. So, the central question seems to be: how should national public policies be structured in order to mitigate the appalling negative impacts of the pandemic on the Brazilian economy (especially regarding unemployment and lack of income), without disregarding the fundamental commitment to health security of populations in tourist destinations, in view of the increase in the situation of disseminated contamination? The objective of the research is to analyze the contradictions that have been established between national public policies for the resumption of Tourism (in the fight against the economic crisis resulting from the Covid-19 pandemic) and the growing insecurity of populations in Brazilian tourist destinations in view of the expansion of the situation. of contamination. The theoretical foundation is based on: theories of the sociology of absences and emergencies, by Boaventura dos Santos; Hannah Arendt (2010) about the rise of the social sphere that undermined the original distinction between public and private, with action (praxis) being one of the fundamental human conditions. The theoretical-methodological path taken in the development of the essay is the multiple case study through the analysis of experiences, and the triangulation of speeches through analytical categories. The discussions that open from there permeate conceptual debates on an ethical foundation of public policies, to mitigate the effects of structural crises, and the current impact of the pandemic that devastates the world scenario. And if these are in the field of mitigation or irresponsible promotion, under the commitment to save jobs, opposing ethical attitudes in the exercise of imposing violence of legal authority, and the principles of public discussion on "mutual commitment and common deliberation".

Keywords: Public Policies in Tourism, Ethics, Covid 19, Tourism Resumption

\section{Authors}

\begin{tabular}{clc}
\hline Full Name & \multicolumn{1}{c}{ Author contribution roles } & Contribution rate \\
\hline Marutschka Moesch: & $\begin{array}{l}\text { Conceptualization, Methodology, Validation, Formal analysis, Investigation, Data Curation, Writing - Original Draft, } \\
\text { Writing - Review \& Editing, Visualization, Supervision, }\end{array}$ \\
\hline João Paulo Tasso: & $\begin{array}{l}\text { Conceptualization, Methodology, Validation, Formal analysis, Investigation, Data Curation, Writing - Original Draft, } \\
\text { Writing - Review \& Editing, Visualization, Supervision, }\end{array}$
\end{tabular}

Author statement: Author(s) declare(s) that All procedures performed in studies involving human participants were in accordance with the ethical standards of the institutional and/or national research committee and with the $1964 \mathrm{Helsinki}$ declaration and its later amendments or comparable ethical standards. Declaration of Conflicting Interests: The author(s) declared no potential conflicts of interest with respect to the research, authorship, and/or publication of this article

This paper does not required ethics committee report

Justification: The methodology of this study does not require an ethics committee report. 